\title{
INTERAKSI ANTARA MAKROFAG DAN JARINGAN ADIPOSA PADA OBESITAS
}

\author{
I Made W. Wardhana \\ Sunny Wangko
}

\author{
Bagian Anatomi-Histologi Fakultas Kedokteran Universitas Sam Ratulangi Manado \\ Email: megaloblastik@yahoo.com
}

\begin{abstract}
In adipose tissues of obese people there is an activation of multiple signaling pathways towards hypertrophic adipocytes, associated with infiltration of macrophages. These cells trigger inflammatory reactions in those tissues, that attract more macrophages from bone marrows; therefore, increasing the reactions. Moreover, there is a paracrine loop that consists of saturated fatty acids and TNF- $\alpha$ derived from macrophages and adipocytes. These two substances create an inflammatory/inflammation cycle, characterized by an up-regulation of pro-inflammatory adipokines and a down-regulation of anti-inflammatory adipokines. Disregulation of adipokines production in adipose tissues of obese people in vivo shows that there is a clear/strong interaction between adipocytes and macrophages in causing a chronic inflammation in the tissues.
\end{abstract}

Keywords: macrophages, adipose tissue, cytokines

\begin{abstract}
Abstrak: Pada jaringan adiposa orang obes terjadi aktivasi multiple signaling pathways terhadap adiposit yang hipertrofi, disertai adanya infiltrasi makrofag. Sel-sel ini memicu terjadinya reaksi inflamasi pada jaringan adiposa tersebut, yang selanjutnya menarik makrofag dari sumsum tulang, dengan akibat meningkatnya proses inflamasi. Selain itu terdapat lengkung parakrin yang meliputi asam lemak jenuh dan TNF- $\alpha$ yang berasal dari makrofag dan adiposit. Kedua bahan tersebut membentuk suatu siklus inflamasi yang ditandai oleh up-regulation dari adipokin pro-inflamasi dan down-regulation dari adipokin anti-inflamasi. Disregulasi produksi adipokin pada jaringan adiposa orang obes in vivo menunjukkan adanya hubungan erat antara adiposit dan makrofag sebagai mekanisme potensial yang menyebabkan inflamasi kronis pada jaringan adiposa.
\end{abstract}

Kata kunci: makrofag, jaringan adiposa, sitokin

Obesitas merupakan suatu penyakit multifaktorial, yang terjadi akibat akumulasi jaringan adiposa berlebihan di dalam tubuh sehingga dapat mengganggu kesehatan. Dewasa ini insidens obesitas di negara-negara berkembang semakin meningkat, dan diperkirakan jumlah penyandang obesitas di dunia hampir sama dengan mereka yang menderita kelaparan. ${ }^{1-5}$

Walaupun belum dipahami secara jelas hubungan antara obesitas dengan penyakitpenyakit komorbidnya, bukti-bukti yang dikemukakan menunjukkan adanya peran ser- ta dari protein yang berasal dari jaringan adiposa (adipose tissue (AT)-derived proteins) yang dikenal sebagai adipokin. Berbagai adipokin ini dapat terlibat baik dalam proses fisiologik maupun patologik. Ketidakseimbangan produksi adipokin pro dan anti-inflamasi dapat dilihat pada obesitas yang memberikan kontribusi besar pada berbagai aspek perkembangan penyakit-penyakit komorbid, antara lain sindroma metabolik. ${ }^{3-5}$

Adipokin tidak hanya diproduksi oleh adiposit; makrofag dalam jaringan adiposa 
juga turut berkontribusi memroduksi adipokin tersebut. ${ }^{4-6}$ Terdapat bukti klinis yang menunjukkan bahwa jaringan adiposa pada obesitas mengalami infiltrasi makrofag, dimana makrofag ini mungkin berpartisipasi dalam proses inflamasi yang diaktifkan oleh jaringan adiposa tersebut. Makrofag yang telah teraktivasi akan menyekresi mediator pro-inflamasi yang maksimal termasuk TNF- $\alpha$, PGE $_{2}$, IL-1, IL-6, spesies oksigen reaktif, dan nitrik oksida, yang akan mempertahankan kelanjutan proses inflamasi yang telah ada. ${ }^{3,7}$ Untuk memahami bagaimana pengadaan makrofag pada jaringan adiposa obes, penting ditelusuri mekanisme molekuler peningkatan produksi kemokin pada tahap awal obesitas

\section{MAKROFAG}

Makrofag merupakan sel yang memberikan respons terhadap rangsangan kemotaksis tertentu (sitokin dan kompleks antigen-antibodi) dan mempunyai kemampuan fagositosis untuk mencerna mikro-organisme dan debris sel. Infiltrasi makrofag ke jaringan adiposa pada obesitas menunjukkan terjadinya inflamasi dengan gradasi rendah pada jaringan tersebut. Penelitian-penelitian pada mencit mengimplikasikan bahwa makrofag-makrofag yang menginfiltrasi jaringan adiposa berasal dari sumsum tulang, dan mungkin didatangkan sebagai respon terhadap kematian dari adiposit (sel lemak) yang hipertrofi dan atau karena sekresi sitokin pro-inflamasi yang berlebihan dari jaringan adiposa, antara lain monocyte chemoattractant protein-1(MCP-1). ${ }^{7-9}$

Makrofag berasal dari proses hematopoiesis sumsum tulang, yang dikendalikan oleh antara lain interleukin-3 (IL-3), macrophage-colony stimulating factor (M-CSF), dan granulocyte macrophage-colony stimulating factor (GM-CSF). Promonosit berproliferasi dan berdiferensiasi menghasilkan monosit yang beredar didalam darah. Monosit yang bermigrasi ke dalam jaringan akan berkembang menjadi makrofag. ${ }^{10,11}$

Dalam keadaan normal, pembaharuan makrofag jaringan terjadi melalui proliferasi lokal dan tidak melalui influks monosit.
Distribusi makrofag dalam jaringan yang luas membuat sel-sel ini sangat cocok untuk memberikan pertahanan segera terhadap partikel asing. Dengan adanya reaksi terhadap partikel asing, monosit baru akan segera bermigrasi ke dalam jaringan. ${ }^{12-18}$ Makrofag derivat M-CSF (M-CSF-derived macrophages) berukuran lebih besar, memiliki kapasitas fagositosis yang lebih tinggi, dan lebih poten terhadap infeksi virus stomatitis vesikular dibandingkan makrofag derivat GM-CSF (GM-CSF-derived macrophages). Sebaliknya, makrofag derivat GM-CSF lebih sitotoksik terhadap tumor yang resisten tumor necrosis factor- $\alpha$ (TNF- $\alpha$ ), lebih mengekspresikan major histocompatibility complex (MHC) kelas II, lebih efisien dalam mematikan Listeria monocytogenes, dan menyekresikan lebih banyak prostaglandin E2 $\left(\mathrm{PGE}_{2}\right)$. IL-2 dan interferon- $\gamma(\mathrm{IFN}-\gamma)$ yang dihasilkan oleh sel $\mathrm{T}_{\mathrm{H}} 1$ atau IL-4 dan IL-10 yang dihasilkan oleh sel $\mathrm{T}_{\mathrm{H}} 2$ pada gilirannya berperan dalam produksi atau aktivasi subset makrofag tertentu. 15,17,19,20

Terdapat dua tahap aktivasi makrofag. Tahap pertama merupakan tahap utama dimana makrofag mengalami peningkatan ekspresi MHC kelas II, presentasi antigen dan konsumsi oksigen, namun kapasitas proliferasinya berkurang. Sitokin yang berperan pada tahap ini adalah IFN- $\gamma$, suatu produk yang dihasilkan oleh sel $\mathrm{T}_{\mathrm{H}} 1$ dan $\mathrm{T}_{\mathrm{H}} 0$. Sitokin lainnya yang turut berperan pada tahap ini adalah IFN- $\alpha$, IFN- $\beta$, IL-3, M-CSF, GM-CSF dan TNF- $\alpha$. Pada tahap kedua, makrofag yang telah melewati tahap pertama akan merespon stimulus sekunder untuk menjadi aktif sepenuhnya, yang ditandai dengan ketidakmampuan untuk berproliferasi, konsumsi oksigen yang tinggi (melalui NADPH oksidase), kemampuan untuk membunuh parasit intraselular dan fakultatif, melisis sel tumor, dan sekresi mediator pro-inflamasi yang maksimal termasuk TNF- $\alpha, \mathrm{PGE}_{2}$, IL-1, IL-6, spesies oksigen reaktif, dan nitrik oksida yang dihasilkan oleh iNOS. Faktor-faktor yang berperan pada tahap kedua ini antara lain lipopolisakarida (LPS), bakteri gram positif, glukan jamur, GM-CSF dan ester forbol. Penelitian mengungkapkan bahwa makrofag yang telah 
teraktivasi ini dapat dideaktivasi oleh prostaglandin E dan beberapa macam steroid. Belakangan ini macrophage deactivating factor $(M D F)$ telah berhasil diisolasi dari sel tumor. Sitokin ini menghambat aktivasi oleh IFN- $\gamma$ untuk meningkatkan kapasitas produksi ROI, nitrik oksida, IL-4, TGF- $\beta$ dan calcitonin gene related peptide (CGRP). ${ }^{13-21}$

\section{ASPEK BIOMOLEKULAR OBESITAS}

Pemahaman jalur molekular yang bertanggungjawab terhadap keadaan inflamasi kronik pada obesitas dipersulit oleh ketidakpastian asal-usul suatu mediator proinflamasi. $^{22}$

Adenosin monophosphate kinase (AMPK) merupakan enzim yang mengatur pembentukan energi dengan mengubah adenosin trifosfat (ATP) menjadi adenosin monofosfat (AMP). AMPK berperan sebagai penghasil energi yang digunakan dalam proses transkripsi protein yang dibutuhkan untuk menghasilkan adipokin pada jaringan adiposa ataupun sitokin yang dihasilkan oleh makrofag. ${ }^{23}$

AMPK merupakan serin-treonin kinase yang saat ini diketahui sebagai pemegang peran kunci kemampuan sel untuk keseimbangan energi yang negatif. Reduksi energi selular yang dicerminkan oleh peningkatan AMP dan reduksi ATP menyebabkan fosforilasi dan aktivasi AMPK yang mempengaruhi ambilan makanan di sentral dan peningkatan sensitivitas insulin serta oksidasi asam lemak di perifer. Aktivitas AMPK diatur oleh pengikat AMP ke pengaturan subunit- $\gamma$ dan fosforilasi katalis subunit- $\alpha$ oleh enzim kinase termasuk LKB1 dan Ca2+/calmodulin-dependent protein kinase $\beta^{24,25}$

AMPK diaktifkan oleh bermacammacam faktor neuroendokrin oreksigenik seperti ghrelin, neuropeptide $Y(N P Y)$, agoutirelated peptide $(A g R P)$, dan adipokin tertentu (sebagai contoh: adiponektin). Di lain pihak AMPK diinhibisi oleh sitokin proinflamasi seperti TNF- $\alpha$, IL-6, dan peptida neuroendokrin anoreksigenik misalnya leptin dan agonis reseptor melonokortin 3,4. Saat aktivasi, AMPK mengatur transkripsi faktor spesifik dan enzim yang umumnya memiliki efek langsung terhadap pengaturan inflamasi. $^{22}$

Aktivator farmakologik AMPK seperti 5-amino-imidazole-4-carboxamide- $1-\beta$-4-ribofuranoside mempengaruhi aktivasi $n u$ clear factor $-\kappa B(\mathrm{NF}-\kappa \mathrm{B})$ terinduksi LPS yang menyebabkan reduksi pengeluaran TNF- $\alpha$, IL-6, dan IL-1 $\beta$ dari sel-sel glia di otak. Aktivasi AMPK juga menghambat inflamasi dan memiliki efek protektif terhadap ensefalomielitis autoimun, fibrosis kistik, dan jaringan adiposa. Terdapat penelitian yang menunjukkan bahwa AMPK memiliki peran kunci dalam mereduksi inflamasi dan memediasi efek kardioprotektif macrophage migration inhibitory factor selama reperfusi cedera iskemik. AMPK juga berperan langsung dalam memediasi kemampuan adiponektin sebagai anti-inflamasi. Bukti-bukti korelatif menunjukkan bahwa reduksi pengeluaran sitokin pro-inflamasi dari sel $\mathrm{T}$ dan monosit yang dimediasi ghrelin dapat juga melalui aktivasi jalur AMPK. Beberapa penelitian juga menunjukkan bahwa ghrelin menghambat sitokin pro-inflamasi dengan mengaktifkan NF-кB. Transkripsi sitokinsitokin pro-inflamasi diatur secara luas oleh aktivasi NF- $\kappa$ B. Mekanisme molekular efek AMPK pada transkripsi sitokin proinflamasi dan potensi untuk interaksi dengan faktor transkripsi kunci seperti NF- $\kappa \mathrm{B}$ masih belum dapat dipastikan. Dengan menganggap bahwa fosforilasi inhibitor kappa $B$ (IкB) merupakan keadaan tergantung ATP maka proses katalitik akan meningkatkan rasio AMP:ATP. Peningkatan konsentrasi selular AMP akan mengaktifkan AMPK yang berperan sebagai "rem metabolik" untuk aktivasi NF- $\mathrm{KB}$ yang mengatur kelanjutan transkripsi sitokin proinflamasi. $^{26,27}$

Jalur mammalian target of rapamycin (mTOR) dan efektor S6 kinase-1 (S6K1) memediasi berbagai efek biologik nutrien, insulin dan energi (Gambar 1). Saat ini telah diketahui bahwa keadaan kelebihan nutrisi akibat mTOR/S6K1 bertanggungjawab terhadap obesitas dan resistensi insulin. Hormon neuroendokrin anoreksigenik leptin diketahui berperan untuk mengaktifkan 


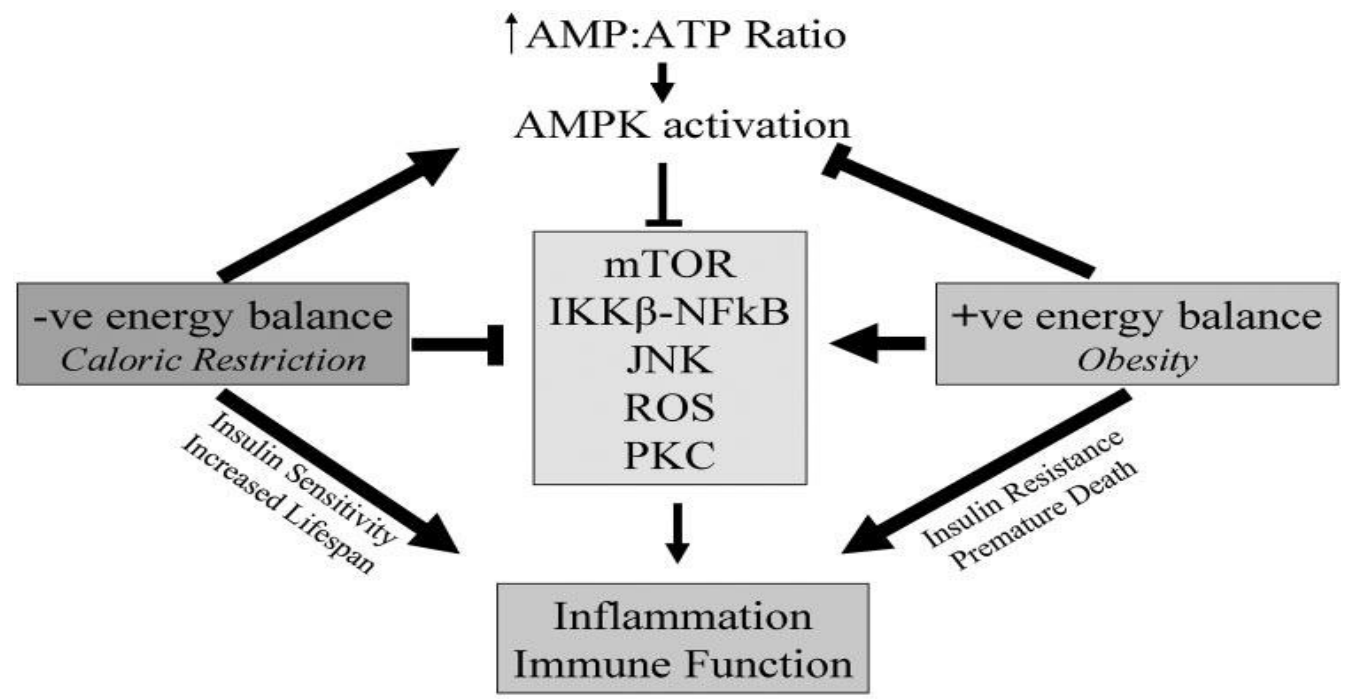

Gambar 1. Peran AMPK sebagai sensor metabolik pusat yang mempengaruhi inflamasi dan sistem imun. Sumber: Dixit, 2008. ${ }^{2}$

mTOR dan menghambat ekspresi AMPK pada sistem saraf pusat. mTOR dan AMPK berperan sebagai "perasa energi", dimana mTOR merupakan tanda kelebihan energi sedangkan AMPK merasakan restriksi energi. Aktivasi tuberous sclerosis complex 2 phosphorylation yang diinduksi oleh AMPK meningkatkan konsentrasi Rheb terikat-GDP, yang bertanggungjawab terhadap reduksi aktivitas mTOR dan turunnya pengunaan energi. Delesi genetik S6K1 efektor mTOR pada mencit meningkatkan pengunaan energi dan melindungi mencit dari diet-induced obesity (DIO). Dengan demikian AMPK berperan dalam keseimbangan energi negatif sedangkan mTOR berperan dalam keseimbangan energi positif; keseimbangan keduanya diatur oleh leptin. $^{22,24}$

\section{PERAN MAKROFAG PADA REMO- DELING JARINGAN ADIPOSA}

Pada obesitas, jaringan adiposa dicirikan oleh hipertrofi adiposit, diikuti dengan peningkatan angiogenesis, infiltrasi sel imun, produksi matriks ekstrasel yang berlebihan, dan peningkatan produksi sitokin pro-inflamasi dalam perjalanan proses inflamasi kronik. Hal ini menjelaskan respons inflamasi kronik pada dinding vaskuler aterosklerosis, dikenal sebagai remodeling vaskular, yang dimediasi oleh interaksi kompleks antara sel endotel vaskuler, sel otot polos vaskuler, limfosit dan makrofag derivat monosit. Perubahan dinamis ini juga dapat dilihat pada jaringan adiposa orang obes (dikenal sebagai remodeling jaringan adiposa), dimana terjadi perubahan sel stroma baik dalam jumlah maupun jenis sel. Remodeling jaringan adiposa dapat dikatakan sebagai proses inflamasi kronik yang melibatkan hipertrofi adiposit, infiltrasi makrofag, dan interaksi adiposit-makrofag (Gambar 2). ${ }^{14,23,24}$

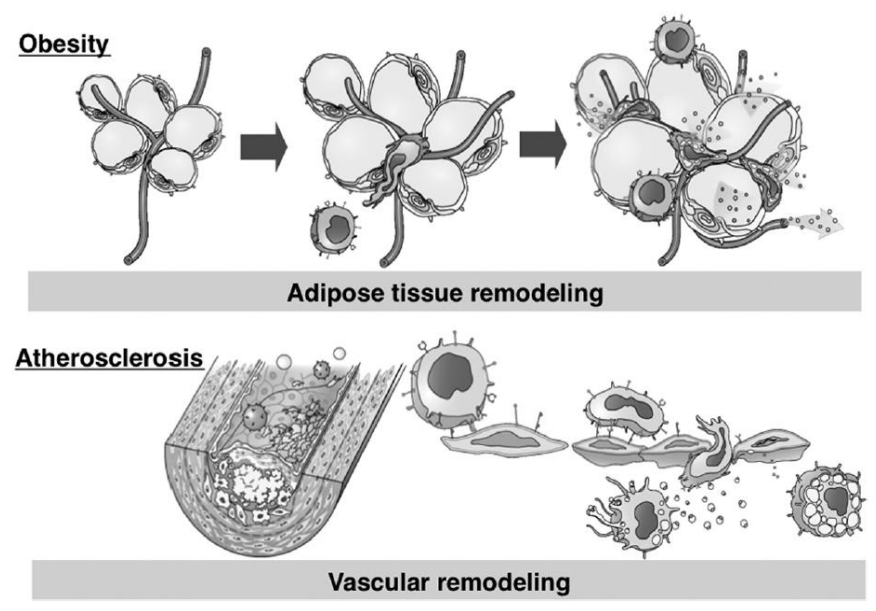

Gambar 2. Remodeling jaringan adiposa. Sumber: Suganami \& Ogawa, 2010. ${ }^{28}$ 
Infiltrasi makrofag, hipertofi adiposit, dan perubahan akibat inflamasi

Penelitian sebelumnya pada transplantasi sumsum tulang menunjukkan bahwa umumnya makrofag jaringan adiposa berasal dari sumsum tulang. Dalam hal ini peningkatan ekspresi sitokin pada jaringan adiposa orang obes bertanggungjawab terhadap pengadaan monosit di jaringan tersebut.

Terdapat bukti bahwa jalur macrophage chemoattractant protein-1 (MCP-1)/C-Chemokine reseptor 2 (CCR-2) berperan dalam patofisiologi infiltrasi makrofag pada jaringan tersebut. MCP-1 dihasilkan oleh adiposit dan makrofag pada jaringan adiposa orang obes. Produksi MCP-1 yang berlebihan pada jaringan adiposa ini menginduksi terjadinya infiltrasi makrofag ke jaringan tersebut yang kemudian menyebabkan inflamasi. MCP-1 juga menginduksi resistensi insulin pada otot skeletal dan hati, menunjukkan adanya peran sebagai hormon endokrin. Weisberg et al. melaporkan adanya akumulasi makrofag dan inflamasi kronis pada jaringan adiposa mencit yang tidak memiliki CCR2 $\left(C C R 2^{-/-}\right.$ mice) dalam diet tinggi lemak. Terlebih lagi, dua studi sebelumnya pada mencit transgenik yang mengekspresikan MCP-1 berlebihan pada jaringan adiposa dan mencit yang mengalami defisiensi MCP-1 menun- jukkan bahwa MCP-1 memiliki peran dalam pengadaan makrofag ke jaringan adiposa mencit obes. Inhibisi infiltrasi makrofag ke jaringan adiposa pada obesitas melalui strategi genetik dan/atau farmakologik menyebabkan disregulasi produksi adipokin, yang mengarah ke terjadinya perbaikan inflamasi jaringan adiposa yang diinduksi obesitas dan resistensi insulin (Gambar 3). ${ }^{15,26,27}$

Untuk memahami bagaimana pengadaan makrofag pada jaringan adiposa orang obes, penting untuk mengetahui mekanisme molekuler peningkatan produksi kemokin pada tahap awal obesitas. Penelitian obesitas in vivo menunjukkan adanya aktivasi multiple signaling pathways pada adiposit yang hipertrofi. $^{29,30}$

Mitogen activating protein kinase (MAPK) merupakan suatu faktor transkripsi yang berperan pada pembentukan sitokin makrofag. Beberapa contoh MAPK seperti ERK, p38 MAPK dan Jun kinase (JNK), diaktifkan oleh proses-proses seluler seperti diferensiasi adiposit dan hipertrofi adiposit. Pada stres retikulum endoplasma, MAPK yang dihasilkan meningkat sehingga semakin memperburuk keseimbangan sitokin pro dan anti-inflamasi. MAPK diinaktifkan secara berantai oleh fosfatase protein seperti MKP-1 (MAPK-fosfatase-1).

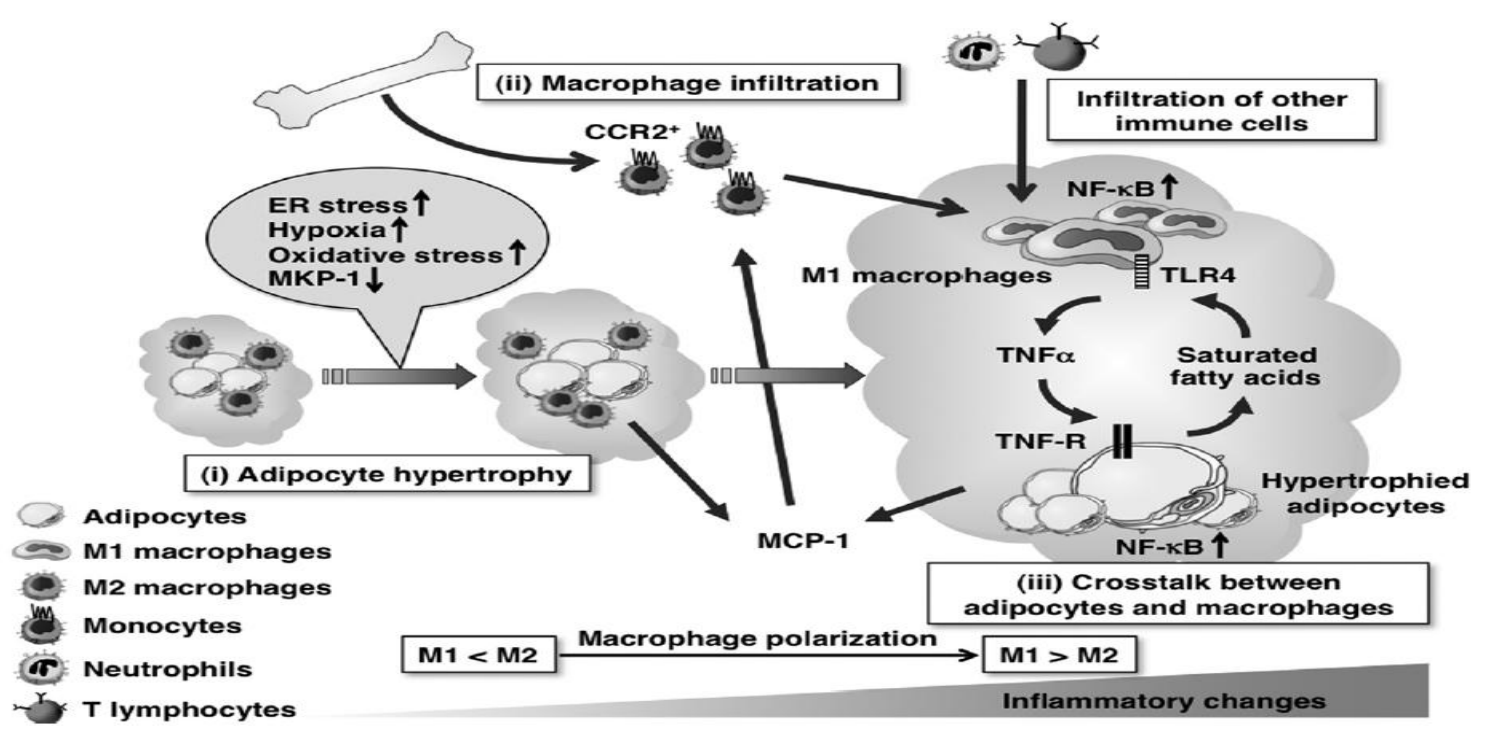

Gambar 3. Mekanisme molekuler yang mendasari inflamasi jaringan adiposa. Sumber: Suganami \& Ogawa, 2010. ${ }^{28}$ 
Telah berhasil ditunjukkan bahwa downregulation MKP-1 penting untuk peningkatan produksi MCP-1 pada keadaan hipertrofi adiposit. Ozcan et al melaporkan bahwa stres retikulum endoplasma pada hati dan jaringan adiposa berperan sentral pada inflamasi jaringan adiposa yang diinduksi obesitas. Hosogai et al kemudian melaporkan bahwa stres retikulum endoplasma yang diinduksi oleh hipoksia berperan dalam disregulasi produksi adipokin. Selanjutnya Furukawa et al menunjukkan bahwa peningkatan produksi reactive oxygen species (ROS) pada hipertrofi adiposit dan stres oksidatif menginduksi terjadinya disregulasi produksi adipokin. ${ }^{17,29,30}$

\section{Lengkung parakrin antara makrofag dan adiposit}

Sekali menginfiltrasi jaringan adiposa pada stadium lanjut obesitas, makrofag akan berpartisipasi dalam jalur inflamasi yang diaktifkan oleh jaringan adiposa tersebut. Dengan kokultur in vitro yang terdiri dari makrofag dan adiposit, telah berhasil dibuktikan adanya lengkung parakrin (paracrine loop) meliputi asam lemak bebas dan TNF- $\alpha$ yang berasal dari makrofag dan adiposit. Kedua bahan tersebut membentuk suatu siklus inflamasi yang ditandai oleh up-regulation dari adipokin pro-inflamasi seperti MCP-1 dan TNF- $\alpha$, dan down-regulation yang bermakna dari adipokin anti-inflamasi. Disregulasi produksi adipokin pada jaringan adiposa orang obes in vivo menunjukkan adanya hubungan erat antara adiposit dan makrofag sebagai mekanisme potensial yang menyebabkan inflamasi kronis pada jaringan adiposa tersebut. TNF- $\alpha$ umumnya berasal dari makrofag yang menginfiltrasi jaringan adiposa pada obesitas, dan berkerja pada reseptor TNF- $\alpha$ adiposit yang hipertrofi, kemudian menginduksi produksi sitokin pro-inflamasi dan lipolisis adiposit melalui mekanisme $N F-\kappa B$-dependent and-independent (possibly MAPK-dependent). Di lain pihak, asam lemak jenuh yang dilepaskan berperan sebagai ligan alamiah untuk kompleks toll like receptor 4 (TLR-4) yang esensial untuk mengenali LPS agar mengin- duksi aktivasi NF- $\kappa$ B pada makrofag. ${ }^{18,19,31}$

Penelitian-penelitian menunjukkan bahwa TLR4 berperan penting dalam inflamasi jaringan adiposa yang diinduksi obesitas serta metabolisme sistemik glukosa dan lipid in vivo. TLR4 diekspresikan oleh makrofag lebih banyak daripada adiposit. Kemungkinan respons inflamasi kronis yang diinduksi oleh interaksi antara adiposit dengan makrofag lebih banyak dimediasi melalui TLR4 makrofag. Saberi et al. menunjukkan bahwa delesi TLR4 pada sel-sel hematopoetik spesifik menyebabkan perbaikan profil lipid serta resistensi insulin pada jaringan adiposa dan hati. Inhibisi makrofag teraktivasi oleh asam lemak jenuh yang berasal dari adiposit dapat dipikirkan memberikan strategi pengobatan untuk mencegah inflamasi jaringan adiposa. Adanya hubungan antagonisme antara asam lemak jenuh dengan asam lemak tak jenuh $n$-3 seperti eicosa pentanoic acid (EPA), menunjukkan bahwa EPA murni meningkatkan adiponektin anti-inflamasi yang seharusnya berkurang pada jaringan adiposa orang obes dengan memutuskan siklus yang diciptakan oleh adiposit dan makrofag. ${ }^{13,19,32,33}$

Disregulasi produksi adipokin yang diinduksi oleh inflamasi jaringan adiposa memiliki peran penting dalam patofisiologi sindrom metabolik dan aterosklerosis. Sebagai contoh mencit obes dengan defisiensi TNF- $\alpha$ terlindung dari resistensi insulin, walaupun TNF- $\alpha$ yang berasal dari makrofag jaringan adiposa meningkat. Diduga terdapat perbedaan kerja antara TNF- $\alpha$ yang dihasilkan makrofag dan jaringan adiposa. ${ }^{34}$

\section{SIMPULAN}

Pada obesitas terjadi suatu proses inflamasi kronik, disertai adanya infiltrasi makrofag yang berasal dari sumsum tulang pada jaringan adiposa. TNF- $\alpha$ yang berasal dari makrofag dan adiposit, serta asam lemak jenuh, keduanya membentuk suatu siklus inflamasi yang ditandai oleh up-regulation dari adipokin pro-inflamasi dan down-regulation dari adipokin anti-inflamasi. Disregulasi produksi adipokin pada jaringan adiposa orang obes in vivo menunjukkan adanya ke- 
terlibatan erat antara adiposit dan makrofag dalam perlangsungan proses inflamasi di jaringan tersebut.

\section{DAFTAR PUSTAKA}

1. Bruun JM, Lihn AS, Pedersen SB, Richelsen B. Monocyte chemoattractant protein-1 release is higher in visceral than subcutaneous human adipose tissue (AT): implication of macrophage resident in the AT. J Clin Endocrinol Metab. 2005;90(4):2282-89.

2. Dixit VD. Adipose-immune interactions during obesity and caloric restriction: reciprocal mechanism regulating immunity and health span. J Leukoc Biol. 2008;84:882-92.

3. Lago F, Dieguez C, Gomez-Reino J, Gualilo O. Adipokines as emerging mediators of immune response and inflammation. Nat Clin Pract Rheumatol. 2007;3(12):716-24.

4. Kumar V, Cotran R, Robbins S. Buku Ajar Patologi (Edisi ke-7). Jakarta: EGC, 2000; p.56-63.

5. Underwood JC. Patologi Umum dan Sistematik Vol 1 (Second Edition). Jakarta: EGC, 1999; p. 247-54.

6. Gordon S, Taylor PR. Monocyte and macrophage heterogeneity. Nat Rev Imumunol. 2005;5(12):953-64.

7. Weisberg SP, Hunter D, Huber R, Lemieux J, Slaymaker S, Vaddi K et al. CCR2 modulates inflammatory and metabolic effects of high-fat feeding. J Clin Invest. 2006;116(1):115-24.

8. Tilg H, Moschen AR. Adipocytokines: mediators linking adipose tissue, inflammation and immunity. Nat Rev Immunol. 2006;6:772-83.

9. Bevelander G, Ramaley JA. Essentials of Histology (Eight Edition). Jakarta: Erlangga, 1988.

10. Leeson CR. Textbook of Histology (First Edition). Jakarta: Binarupa Aksara, 1966.

11. Junqueira LC, Carneiro J. Basic Histology: Text \& Atlas (Eleventh Edition). New York: McGraw-Hill Companies, 2005.

12. Gordon S, Taylor PR. Monocyte and macrophage heterogeneity. Nat Rev Immunol. 2005;5:953-64.

13. Mosser DM. The many faces of macrophage activation. J Leukoc Biol.
2003;73:209-12.

14. Martinez FO, Gordon S, Locati M, Mantovani A. Transcriptional profiling of the human monocyte-to-macrophage differentiation and polarization: new molecules and patterns of gene expression. J Immunol. 2006;177:7303-11.

15. Mantovani A, Sica A, Sozzani S, Allavena P, Vecchi A, Locati M. The chemokine system in diverse forms of macrophage activation and polarization. Trends Immunol. 2004;25:677-86.

16. Sica A, Schioppa T, Mantovani A, Allavena P. Tumour-associated macrophages are a distinct M2 polarised population promoting tumour progression: potential targets of anti-cancer therapy. Eur J Cancer. 2006;42: 717-27.

17. Deguchi JO, Aikawa M, Tung CH, Aikawa E, Kim DE, Ntziachristos $V$ et al. Inflammation in atherosclerosis: visualizing matrix metalloproteinase action in macrophages in vivo. Circulation. 2006;114:55-62.

18. Bouloumie A, Curat CA, Sengenes C, Lolmede $\mathrm{K}$, Miranville A, Busse $\mathrm{R}$. Role of macrophage tissue infiltration in metabolic diseases. Curr Opin Clin Nutr Metab Care. 2005;8:347-54.

19. Curat CA, Miranville A, Sengenes C, Diehl M, Tonus C, Busse R et al. From blood monocytes to adipose tissueresident macrophages: induction of diapedesis by human mature adipocytes. Diabetes. 2004;53:1285-92.

20. Curat CA, Wegner V, Sengenes $C$, Miranville A, Tonus C, Busse R et al. Macrophages in human visceral adipose tissue: increased accumulation in obesity and a source of resistin and visfatin. Diabetologia. 2006;49:744-7.

21. Cancello R, Tordjman J, Poitou C, Guilhem G, Bouillot JL, Hugol D et al. Increased infiltration of macrophages in omental adipose tissue is associated with marked hepatic lesions in morbid human obesity. Diabetes. 2006;55:1554-61.

22. Kern PA, Di Gregorio GB, Lu T, Rassouli N, Ranganathan G. Adiponectin expression from human adipose tissue; relation to obesity, insulin resistance, and tumor necrosis factor- $\alpha$ expression. Diabetes. 2003;52:1779-85.

23. Xu H, Barnes GT, Yang Q, Tan G, Yang D, Chou CJ et al. Chronic inflammation 
in fat plays a crucial role in the development of obesity-related insulin resistance. J Clin Invest. 2003;112:1821-30.

24. Lumeng CN, Bodzin JL, Saltiel AR. Obesity induces a phenotypic switch in adipose tissue macrophage polarization. $\mathbf{J}$ Clin Invest. 2007;117:175-84.

25. Odegaard JI, Ricardo-Gonzalez RR, Goforth MH, Morel CR, Subramanian V, Mukundan $\mathbf{L}$ et al. Macrophagespecific PPARgamma controls alternative activation and improves insulin resistance. Nature. 2007;487:1116-20.

26. Schneemann M, Schoeden G. Macrophage biology and immunology: man is not a mouse. J Leukoc Biol. 2007;81:579.

27. Ahima RS, Flier JS. Adipose tissue as an endocrine organ. Trends Endocrinol Metab. 2000;11:327-32.

28. Suganami T, Ogawa Y. Adipose tissue macrophages: their role in adipose tissue remodeling. J Leuko Biol. 2010;88:1-7.
29. Bray GA. Medical consequences of obesity. J Clin Endocrinol Metab. 2004;89:2583-89.

30. Fruhbeck G, Gomez-Ambrosi J, Muruzabal FJ, Burrell MA. The adipocyte: a model for integration of endocrine and metabolic signaling in energy metabolism regulation. Am J Physiol Endocrinol Metab. 2001; 280(6):E827-47.

31. Kershaw EE, Flier JS. Adipose tissue as an endocrine organ. The Journal of Clinical Endocrinology \& Metabolism. 2004; 89(6): 2548-56.

32. Miner JL. The adipocyte as an endocrine cell. J Anim Sci. 2004;82:935-41

33. Diamon F. The endocrine function of adipose tissue. Growth Gen Horm. 2002; 18:17-22.

34. Novakofski J. Adipogenesis: Usefulness of in vitro and in vivo experimental models. J Anim Sci. 2004;82:905-15. 